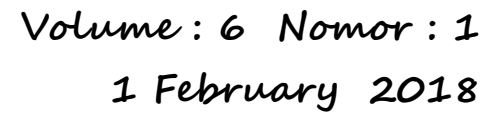

\title{
IDENTIFIKASI TUMBUHAN BERMANFAAT DALAM KEHIDUPAN MASYARAKAT SENTANI BARAT SEBAGAI SUMBER BELAJAR IPA PADA MATERI KEANEKARAGAMAN TUMBUHAN SISWA KELAS VII SMP NEGERI SATU ATAP SABRON SARI
}

\author{
Henny Marlina ${ }^{1),}$ Tiurlina Siregar ${ }^{2)}$ \\ ${ }^{1}$ Alumni Program Studi Magister Pendidikan IPA Universitas Cenderawasih \\ ${ }^{2}$ Dosen Program Studi Magister Pendidikan IPA Universitas Cenderawasih
}

Abstract Research on Identification of Beneficial Plant In West Sentani Community Life as a Learning Resource Materials Science On Plant Diversity Seventh Grade Students of SMP One Roof Sabron sari. This study aims to: 1). To find out how to use the environment as a learning resource; 2). To identify herbs used in the West Sentani community life; 3). To determine student interest in learning to identify plants around the school: 4). To determine the students' skills in identification.

This research is a qualitative research. Methods or techniques of data collection conducted a descriptive one that is interactive.

The results showed that: 1). By way of using the environment as a learning resource can provide a real experience, direct and attractive to students, through a collection of plants were obtained. 2). By way of directly observing and comparing the characteristics of plants that used sentani western societies are able to decide 4 Division, Grades 5, 20 Nations, 24 tribes, 29 Marga, and 30 types of plants. 3). The increased interest of student learning $75.11 \%$ by using the environment as a learning resource IPA. 4). $67.16 \%$ of students skilled in identifying plants scientifically and correctly. The benefits that can be taken by students is that students can take advantage of the environment as a learning resource, it can identify the types of plants are found, learning and student skills in the use of the environment as a learning resource in both categories.

Keywords: Identification of Plants, Plant helpful and Junior High School Students One Roof Sabron Sari class VII

Abstrak Penelitian tentang Identifikasi Tumbuhan Bermanfaat Dalam Kehidupan
Masyarakat Sentani Barat Sebagai Sumber Belajar IPA Pada Materi Keanekaragaman
Tumbuhan Siswa Kelas VII SMP Negeri Satu Atap Sabron sariPenelitian ini bertujuan untuk
: 1). Untuk mengetahui cara memanfaatkan lingkungan sebagai sumber belajar ; 2). Untuk
mengidentifikasi tumbuhan yang digunakan dalam kehidupan masyarakat Sentani Barat ; 3).
Untuk mengetahui minat belajar siswa dengan mengidentifikasi tumbuhan di sekitar
lingkungan sekolah : 4). Untuk mengetahui keterampilan siswa dalam melakukan
identifikasi.
Jenis penelitian ini adalah penelitian kualitatif. Metode atau teknik pengumpulan data yang
dilakukan berbentuk deskriptif yang bersifat interaktif.
Hasil penelitian menunjukkan bahwa : 1). Dengan cara memanfaatkan lingkungan sebagai
sumber belajar dapat memberikan pengalaman nyata, langsung dan menarik kepada siswa,
melalui koleksi tumbuh-tumbuhan yang di peroleh.
langsung ciri-ciri dan membandingkan tumbuhan yang dimanfaatkan masyarakat sentani 
barat siswa dapat menentukan 4 Divisi, 5 Kelas, 20 Bangsa, 24 Suku, 29 Marga, dan 30 Jenis tanaman. 3). Terjadinya peningkatan minat belajar siswa $75,11 \%$ dengan memanfaatkan lingkungan sebagai sumber belajar IPA. 4). 67,16\% siswa trampil dalam mengidentifikasi tumbuhan secara ilmiah dan benar. Manfaat yang dapat diambil oleh siswa adalah siswa dapat memanfaatkan lingkungan sebagai sumber belajar, dapat mengidentifikasi jenis-jenis tumbuhan yang ditemukan, minat belajar dan keterampilan siswa dalam pemanfaatan lingkungan sebagai sumber belajar dalam kategori baik.

Kata Kunci: Identifikasi Tumbuhan, Tumbuhan bermanfaat, dan Siswa SMP Negeri Satu Atap Sabron Sari kelas VII

\section{PENDAHULUAN}

\subsection{Latar Belakang}

Lingkungan merupakan salah satu sumber belajar IPA yang sangat penting dan memiliki nilai-nilai yang sangat berharga dalam proses pembelajaran siswa. Lingkungan dapat memperkaya bahan dan kegiatan belajar. Dengan mengambil bahan belajar IPA dari lingkungan siswa, maka kecakapan dan kepandaian siswa dapat dipraktekkan dalam kehidupan bermasyarakat.

Dalam rangka untuk memperoleh pengetahuan yang mendalam tentang sesuatu siswa memerlukan banyak pengalaman haruslah terkait dengan keadaan yang nyata dan ada di sekelilingnya. Untuk itu, siswa dituntut untuk dapat memanfaatkan lingkungan yang ada disekitarnya sebagai sumber belajar.

Wiowati dalam Maria, (2015) mengemukakan bahwa potensi lokal sekolah yang berupa lingkungan dapat menjadi salah satu sumber belajar. Belajar dengan menggunakan apa yang ada dalam kehidupan sehari-hari memungkinkan siswa menemukan hubungan yang sangat bermakna antara ide-ide abstrak yang penerapan praktis secara kontekstual.. Program pembelajaran merupakan rangkaian skenario tentang apa yang harus dipelajari dan bagaimana mempelajarinya yang telah direncanakan.

Pemanfaatkan potensi lokal di lingkungan sekolah, guru harus peka terhadap gejala yang terhampar di lingkungan (alam). Kepekaan tersebut perlu dilatih karena bukan hal yang sederhana, terbiasa memperhatikan alam maka sebagian besar guru masih kurang menyadari bahwa alam menyajikan berbagai persoalan pembelajaran melalui gejala-gejala yang dimunculkan. Sebagian besar guru masih berasumsi bahwa untuk menjelaskan suatu konsep kepada siswa maka guru berceramah tentang konsep 
tersebut yang terjadi sebagaimana yang tertulis di buku teks, padahal gejala dan contoh nyata dapat di amati di lingkungan alam sekitar. Oleh karena itu, perlu bagi guru untuk memahami dan memiliki keterampilan mengidentivikasi dan mengorganisasikan potensi lokal sekolah dalam mewujudkan pembelajaran IPA.

Sumber pembelajaran yang dilakukan oleh komunitas masyarakat atau aktifitas masyarakat sehari-hari, dapat dijadikan sebagai sumber pembelajaran, oleh sebab itu siswa dapat mengetahui halhal yang terjadi dilingkungan sekitar dan lebih memahami dalam pembelajaran IPA khususnya Biologi. Belajar biologi dapat diartikan sebagai belajar tentang mahluk hidup yang mencakup semua fenomena hidup dari mikroorganisme, tumbuhan dan hewan termasuk manusia.

Oleh sebab itu berdasarkan latar belakang yang telah dikemukakan maka peneliti berkeinginan untuk membuat meneliti dengan judul "Identifikasi Tumbuhan Bermanfaat dalam Kehidupan Masyarakat Sentani Barat Sebagai Sumber Belajar IPA Pada Materi Keanekaragaman Tumbuhan Siswa kelas VII SMP Negeri Satu Atap Sabron Sari".

\subsection{Rumusan Masalah.}

Beberapa masaalah yang akan dikaji dalam penelitian ini menyangkut :
1. Bagaimana cara memanfaakan lingkungan sebagai sumber belajar siswa di kelas VII SMP Negeri Satu Atap Sabron Sari?

2. Bagaimana cara siswa mengidentifikasi tumbuhan yang bermanfaat bagi masyarakat di sekitar lingkungan SMP Negeri Satu Atap Sabron Sari?

3. Apakah minat belajar siswa kelas VII SMP Negeri Satu Atap Sabron Sari dapat meningkat dengan mengidentifikasi tumbuhan di sekitar lingkungan sekolah sebagai sumber belajar materi keanekaragaman tumbuhan?

4. Bagaimana keterampilan siswa dalam melakukan identifikasi tumbuhan yang bermanfaat bagi masyarakat di sekitar lingkungan sekolah secara ilmiah dengan benar?

\subsection{Tujuan Penelitian}

Tujuan dalam penelitian ini adalah untuk mengetahui:

1. Siswa dapat memanfaatkan sumber daya lingkungan sebagai sumber belajar siswa kelas VII SMP Negeri Satu Atap Sabron Sari.

2. Siswa dapat mengidentifikasi tumbuhan yang bermanfaat bagi masyarakat di sekitar lingkungan SMP Negeri Satu Atap Sabron Sari dengan benar. 
3. Terjadinya peningkatan minat belajar siswa kelas VII SMP Negeri Satu Atap Sabron Sari dengan mengidentifikasi tumbuhan di sekitar lingkungan sekolah sebagai sumber belajar materi keanekaragaman tumbuhan.

4. Siswa trampil dalam melakukan identifikasi tumbuhan yang bermanfaat bagi masyarakat di sekitar lingkungan sekolah secara ilmiah dengan benar.

\section{METODOLOGI PENELITIAN}

\subsection{Lokasi, Waktu, dan}

\section{SubjekPenelitian}

Penelitian dilaksanakan di Distrik

Sentani Barat Kabupaten Jayapura.

Penelitian ini dilksanakan bulan Oktober 2016 sampai bulan November 2016.

\subsection{Sumber Data}

Peneliti dalam penelitian ini menggunakan berbagai macam sumber data yaitu :

a. Responden

Responden dalam penelitian ini adalah tokoh masyarakat dan/atau masyarakat Sentani Barat.

b. Sumber Tertulis (cerita rakyat)

c. Sumber Tempat dan Peristiwa

2.3. Metode Pengumpulan data

Metode pengumpulan data yang digunakan dalam penelitian ini antara lain:
a. Metode Angket atau
Kuesioner
b. Metode Dokumentasi

\subsection{Teknik Pengumpulan Data}

Teknik pengumpulan data yang digunakan melalui :

a. Observasi

b. Wawancara

c. Dokumentasi

III. HASIL PENELITIAN

\subsection{Memanfaatkan lingkungan sebagai sumber belajar}

Beberapa hal yang perlu di pertimbangan dalam menentukan lingkungan sekitar sebagai sumber belajar, yaitu Sumber tersebut mudah di jangkau, Tidak memerlukan biaya tinggi, tempat tersebut cukup aman digunakan sebagai sumber belajar dan berkaitan dengan materi yang diajarkan disekolah. http://www.blogbarabai.com/2014/

memanfaatkan-lingkungan-sebagai.html

\subsection{Identifikasi Tumbuhan Bermanfaat dalam Kehidupan Masyarakat Sentani Barat}

Masyarakat Sentani Barat memanfaatkan sumber daya alam dengan penggunaan tumbuhan sebagai obatobatan maupun dikonsumsi sehari-hari.

\subsection{Minat belajar IPA melaui kegiatan mengidentifikasi tumbuhan di lingkungan sekolah.}

. Hasil penelitian dapat di lihat dari perhitungan persentase tumbuhnya minat siswa untuk belajar disekitar lingkungan sekolah. Pengelolaan $\rightarrow$ data untuk menghitung minat belajar siswa 
menggunakan skala Likert, dengan pilihan jawaban sangat setuju (SS), setuju (S), tidak setuju (TS), dan sangat tidak setuju (STS). Jawaban sangat setuju (SS) diberi skor 4, setuju (S) diberi skor 3, tidak setuju (TS) diberi skor 2, dan sangat tidak setuju (STS) diberi skor 1. Data hasil perhitungan dapat dilihat seperti pada gambar 3.1

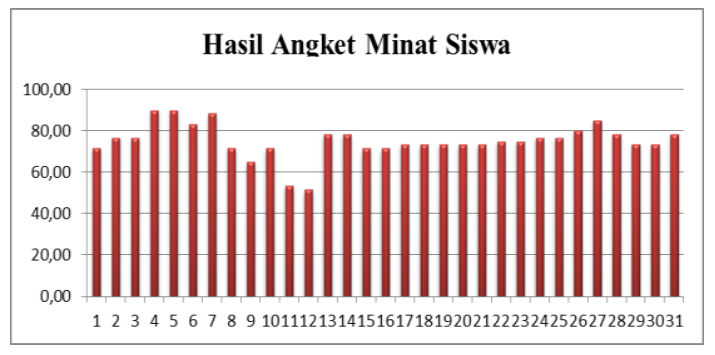

Gambar 3.1 Diagram Hasil Minat Belajar Siswa dalam

Mengidentifikasi Tumbuhan di Sekitar Lingkungan

Sekolah

Berdasarkan Gambar 3.1 diperoleh hasil presentase minat belajar siswa dalam mengklasifikasi tumbuhan di sekitar lingkungan sekolah yaitu nilai 51,67 untuk presentase terendah, 90,00 untuk presentase tertinggi.

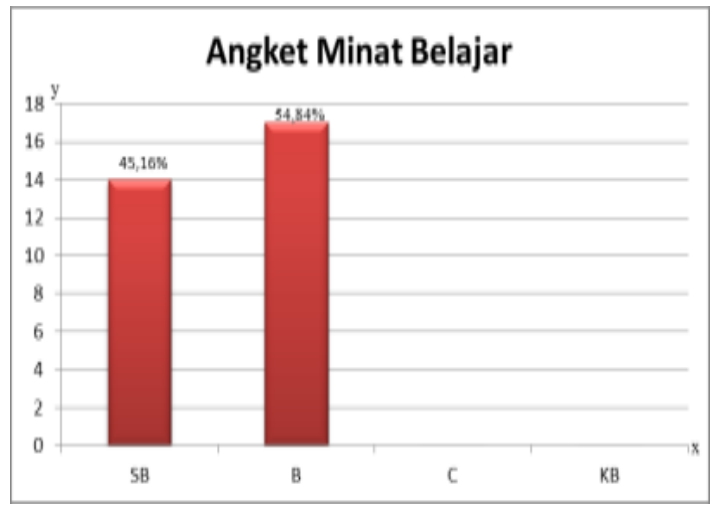

Gambar 3.2 Diagram Hasil Minat Belajar Siswa
Berdasarkan Gambar 3.2

diperoleh hasil presentase minat belajar siswa dalam mengklasifikasi tumbuhan di sekitar masyarakat sentani barat menunjukan $45,16 \%$ (14 siswa) berkreteria sangat baik dan 54,84\% (17 siswa) berkreteria baik.

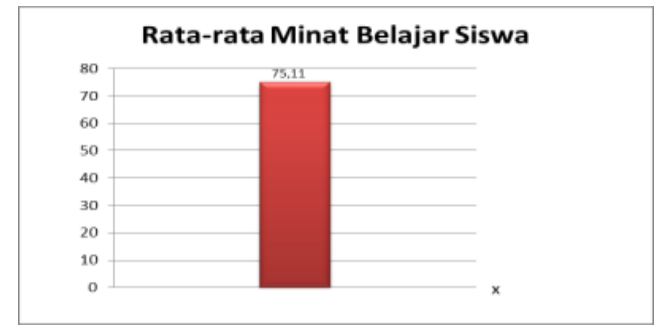

Gambar 3.3 Diagram Hasil Rata-rata Belajar Siswa dalam Mengidentifikasi Tumbuhan di Sekitar Lingkungan Sekolah

Berdasarkan Gambar 3.3 maka diperoleh hasil rata-rata minat belajar siswa dalam mengidentifikasi yaitu presentase sebesar 75,11 dengan kategori sangat baik sehingga dapat disimpulkan bahwa siswa sangat baik dalam mengidentifikasi tumbuhan di sekitar lingkungan sekolah.

\subsection{Keterampilan siswa dalam melakukan identifikasi tumbuhan secara ilmiah.}

Hasil penelitian menunjukkan bahwa presentase keterampilan siswa melakukan identifikasi tumbuhan 
ditunjukkan pada Gambar 3.4 sebagai berikut:

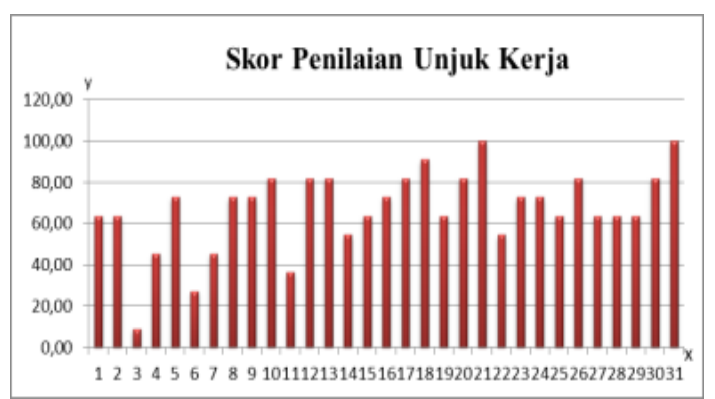

Gambar 3.4 Diagram Hasil Keterampilan Siswa Dalam

Melakukan IdentifikasiTumbuhan di Sekitar Sentani Barat

Berdasarkan hasil pada Gambar 3.4

maka diperoleh hasil keterampilan siswa dalam melakukan identifikasi tumbuhan yaitu 9,09 untuk presentase terendah dan 100 untuk presentase tertinggi.

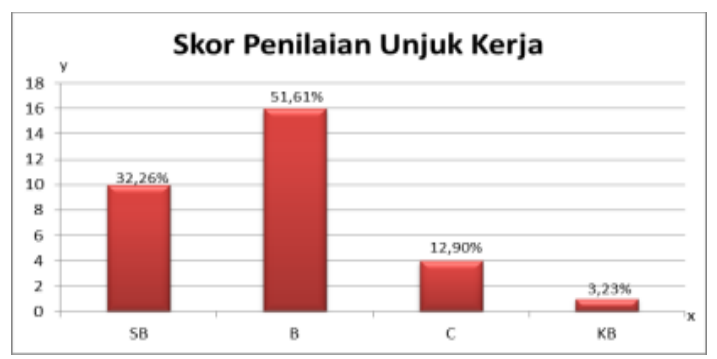

Gambar 3.5 Diagram siswa yang trampil dalam melakukanIdentifikasiTumbuhan

Berdasarkan hasil pada Gambar3.5 maka diperoleh 32,26\% (10 siswa) trampil dalam melakukan identifikasi dengan kriteria sangat baik, 51,61\% (16 siswa) trampil dalam melakukan identifikasi dengan kriteria baik, sedangkan 12,90\% (4 siswa) dengan kriteria cukup dan 3,23\% (1 siswa) dengan kriteria kurang baik.

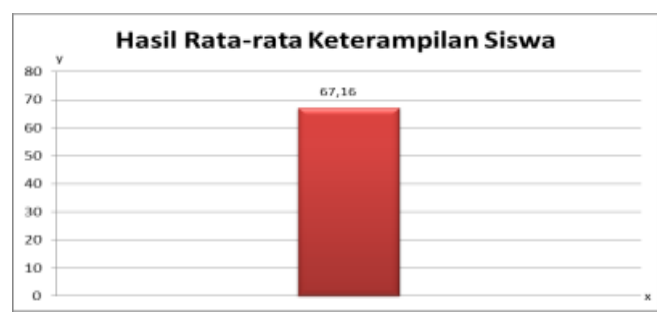

Gambar 3.6 Diagram Hasil Rata-rata Keterampilan Siswa Dalam Melakukan Identifikasi Tumbuhan.

Berdasarkan Gambar 3.6 maka diperoleh hasil rata-rata keterampilan siswa dalam melakukan identifikasi tumbuhan yaitu 67,16. Hasil rata-rata dapat disimpulkan bahwa keterampilan siswa yaitu baik dalam melakukan identifikasi tumbuhan yang bermanfaat bagi masyarakat di sekitar Sentani Barat.

\section{PEMBAHASAN}

\subsection{Pemanfaatan lingkungan sebagai sumber belajar siswa di kelas VII SMP Negeri Satu Atap Sabron Sari}

Pembelajaran yang menjadikan lingkungan sebagai objek belajar dapat memberikan pengalaman nyata dan langsung kepada peserta didik. Secara tradisional, sumber belajar adalah guru dan buku paket. Pada sumber belajar yang ada di sekitar sekolah, di rumah dan lingkungan masyarakat. Sumber belajar dilingkungan sekolah masih banyak yang belum dimanfaatkan secara maksimal.

Beberapa tahapan-tahapan untuk pemanfaatan lingkungan sebagaai sumber belajar, yaitu sebagai berikut: 
a. Tahap Persiapan.

Menyiapkan instrumen- instrumen yang sesuai dengan lembar pengamatan, pedoman wawancara, kuisioner dan fasilitas-fasilitas yang diperlukan untuk studi lapangan

b. Tahap Pelaksanaan.

Mencipatakan suasana yang mendukung agar siswa tertarik dan tertantang melakukan kegiatan dengan sebaik-baiknya.

c. Tahap Pasca Kegiatan Lapangan.

Hasil dari kegiatannya dapat dipresentasikan oleh siswa. Hal ini relevan dengan hasil penelitian Arsana M (2013) bahwa aktivitas belajar siswa setelah inplementasi pendekatan pembelajaran kontekstual berbantuan media lingkungan sekitar pada mata pelajaran IPA siswa kelas IVB SD dapat ditingkatkan secara signifikan dan positif dalam pembelajaran kontekstual berbantuan media lingkungan sekitar pada mata pelajaran IPA. Tanaman yang ditemukan di lingkungan masyarakat Sentani Barat di bawa kesekolah kemudian bersama siswa mengidentifikasi tanaman tersebut. Klasifikasi dari tanaman coklat : Kingdom : Plantae, Divisi : Spermatopyta, Class : Dicotylledoneae, Ordo : Malvales, Famili : Sterculiaceae, Genus :
Theobroma, Spesies : Theobroma cacao L. mengandung alkaloid seperti teobromin, fenetilamin, dan anandamida yang memiliki efek fisiologi untuk tubuh. Dari penelitian coklat dapat menghambat sel kangker dan mengurangi peradangan. (https: //moetzsyifa.wordpress. com/2011/07/24/kandungan-coklat).

Kandungan ini yang membuat buah coklat dapat meredahkan bisul. Dari informasi yang di dapat memberikan informasi baru untuk siswa.

Pemanfaatan lingkungan memungkinkan terjadinya proses belajar yang lebih bermakna, sebab siswa dihadapkan dengan keadaan dan situasi yang sebenarnya. Selain itu pemanfaatan lingkungan sebagai sumber belajar akan mendorong pada penghayatan nilai-nilai atau aspek-aspek kehidupan yang ada di lingkungannya.Cara siswa mengidentifikasi tumbuhan yang bermanfaabagi masyarakat di Sentani Barat sebagai sumber belajar IPA pada materi keanekaragaman tumbuhan siswa kelas VII SMP Negeri Satu AtapS abron Sari.

Tumbuhan yang dapat dimanfaatkan sebagai tanaman obat oleh masyarakat di sekitar lingkungan sekolah hasil pengamatan ditemukan 4 Divisi yaitu : Magnoliophyta, Pteridophyta, 
Spermatophyta, dan Traceophyta ; 5 Kelas yaitu : Angiospermae, Dicotyledoneae, Liliopsida, Magnoliopsida, dan Pterdopsida ; 20 Bangsa; 24 suku; 29 marga; 30 jenis yaitu : Abelmoschus Manihot, Aloe vera, Alpina galanga, Altenanthera amoena, Annona muricata, Annona reticulata, Apiumg raveolens, Areca catechu, Carica papaya, Cocos nucifera, Curcuma domestika, Cymbopogon citratus, Diplazium esculentu, Gynura procumbens, Metrooxylo nsagu, Mimosa pudica, Momordica charantia, Morinda citrifolia, Moringa oleifera, Pandanus conoideus, Persea americana, Phaleria macrocarpa, Piper bettle, Psidium guajava, Ricinus communis, Setaria palmifolia, Solenostemon scutellarioides, Storbilanthescrispa, Theobroma cacao, dan Zingiber purpureum.

Hal ini relevan dengan hasil penelitian dari Maria L. Tumang (2015) yang menunjukan bahwa inventarisasi tumbuhan yang digunakan dalam aktivitas masyarakat sentani timur sebagai sumber belajar biologi pada materi keanekaragaman mahluk hidup

\subsection{Minat belajar siswa kelas VII SMP Negeri SatuAtap Sabron Sari}

Berdasarkan hasil penelitian minat belajar siswa kelas VII SMP Negeri Satu
AtapS abron Sari dengan mengidentifikasi tumbuhan di sekitar lingkungan sekolah pada keanekaragaman tumbuhan tergolong baik dilihat dari hasil presentase minat belajar siswa dimana $51,67 \%$ untuk nilai terendah, $90,00 \%$ untuk nilai tertinggi dengan rata-rata minat belajar siswa $75,11 \%$ hal ini menunjukkan bahwa minat belajar siswa kelas VII SMP Negeri Satu Atap Sabron Sari meningkat pada kelompok siswa dari pada belajar individu.

Hal ini relevan dengan hasil penelitian dari Palupi YS (2014) yang menunjukkan bahwa hasil pengembangan produk media pembelajaran dapat memfasilitasi sistem pembelajaran berpusat pada siswa serta memiliki sajian yang menarik, mudah, dan murah sehingga belajar menjadi lebih menyenangkan, pengembangan media pembelajaran ini mengacu pada Kurikulum 2013

\subsection{Keterampilan siswa dalamm elakukani dentifikasi tumbuhan}

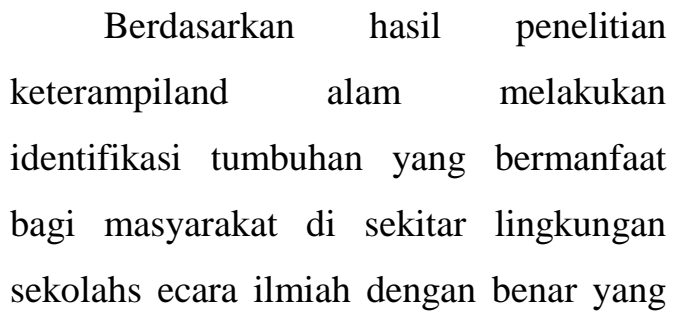


dilakukan oleh siswa tergolong baik,tdiketahuidari perolehan hasil 9,09\% untuk terendah dan $100 \%$ untuk tertinggi, sehingga diperoleh nilai rata-rata keterampilan dalam melakukan identifikasi yaitu $67,16 \%$ dengan kategori baik.

Hal ini relevan dengan hasil penelitian dari Sudarto (2010) yang menunjukan hasil penelitian 1). Terdapat pengaruh pemanfaatan lingkungan sebagai sumber belajarte rhadap hasil belajar IPS siswa SMP Institut Indonesia Semarang, hal ini ditunjukkan dengan $\mathrm{F}$ hitung 3,825 dengan sig 0,$000 ; 2)$. Terdapat pengaruh motivasi belajar terhadap hasilbelajar IPS siswa SMP Institut Indonesia Semarang, hal ini ditunjukkan $\mathrm{F}$ hitung 1,637 dengan sig 0,045 ; 3) Terdapat interaksi antara pemanfataan lingkungan sebagai sumber belajar dan motivasi belajar terhadap hasil belajar IPS siswa di SMP Institut Indonesia Semarang hal ini ditunjukkan dengan F hitung 2,957 dan sig 0,003.

\section{DAFTAR PUSTAKA}

Arsana M, 2013. Implementasi Pendekatan Pembelajaran Kontekstual Berbatuan Media Lingkungan Sekitar Untuk Meningkatkan Aktifitas Dan Hasil Belajar IPA. e-Journal Program Pascasarjana Universitas Pendidikan Ganesha Volume 3.

Hamalik, Oemar. 2001. Psikologi Belajar dan Mengajar. Bandung: Sinar Harapan

Hartaty, Triangulasi dalam penelitian kualitatif,

(https://hartatyfatsyaf.blogspot.co.id diunduh 22 mei 2016)

Maria LT. 2015. Tesis "Inventarisasi Tumbuhan yang digunakan dalam aktivitas masyarakat Sentani Timur sebagai sumber belajar Biologi pada materi Keanekaragaman Mahluk Hidup siswa kelas VII SMP Negeri 1 Sentani". Uncen. Jayapura.

Palupi YS (2014). Pengembangan Media Pembelajaran Dengan Windows Movie Makre (WMM) Pada Topik Klasifikasi Mahkluk Mata Pelajaran IPA Kelas VII Sekolah Menengah Pertama (SMP) St. Bonaventura Sentani. Uncen Jayapura.

Sridianti, Struktur dan fungsi Akar. (http://www.sridianti.com/struktur-fungsiakar-tumbuhan. diunduh 9 april 2016)

Sridanti, Struktur fungsi batang dikotil dan monokotil. ( http ://www. sridianti. com/struktur-fungsi-batang-dikotilmonokotil. diunduh 9 april 2016)

Sudarto, 2010. Pengaruh Pemanfaatan Lingkungan Sebagai Sumber Belajar Dan Motivasi Belajar Siswa Terhadap Hasil Belajar IPS Pada Siswa SMP Institut Indonesia Semarang. Universitas Sebelas Maret. Surakarta

Syamsuri M.Pd. 2007. IPA Biologi Untuk SMP kelas VII. Erlangga. Jakarta.

Wahono widodo, dkk. 2014. Ilmu Pengetahuan Alam.

Yohana dan Yovita, Tanaman Obat Keluarga. Jakarta. Setia Kawan 